\title{
Characterization and Use of Mangifera indica L. Seeds from Four Varieties
}

\author{
Paula X. Villanueva, * Yalile C. Ávila, Lina R. Dávila, John J. Méndez, and Walter \\ Murillo Arango
}

\begin{abstract}
Chemical compositions (fatty acids, total phenolic compounds, flavonoids) and the in-vitro biological activities (antioxidant and antimicrobial activity; and growth induction of edible fungal strains) were compared for four varieties of mango seeds. Hexanic extract $(\mathrm{HE})$ showed a fatty acid profile with a higher proportion of oleic acid. In the ethanolic extract were found variable total phenolic contents (103 to $125 \mathrm{mg} \mathrm{GAE} / \mathrm{g}$ dry weight) and flavonoid contents ( 0.72 to $0.8 \mathrm{mg} \mathrm{QE} / \mathrm{g}$ dry weight). This study reports for the first time the presence of procyanidin B1 in ethanolic extracts. The antioxidant activity showed $\mathrm{IC}_{50}$ values ranging from 3.09 to $3.42 \mu \mathrm{g} / \mathrm{mL}$ for ABTS •+ and 12.17 to $13.93 \mu \mathrm{g} / \mathrm{mL}$ for DPPH•. The ethanolic extract from the seed of the Yulima variety showed the highest percentages of inhibition against Staphylococcus aureus. Residues removed from ethanolic extraction of the seed kernel (EKR) induced the growth of edible fungal strains: Lentinus crinitus and Pleurotus tubarius. The data obtained show the potential of the seeds from these mango varieties, which could lead to alternative uses in various industry sectors and the use of this agricultural byproduct.
\end{abstract}

Keywords: Mango seed kernel; Polyphenols; Antioxidant; Flavonoids; Antimicrobial; Fatty acids; Edible fungi

Contact information: Grupo de Investigación en Productos Naturales de la Universidad del Tolima, GIPRONUT, Chemistry Department, Science Faculty, University of Tolima, 730006, Ibagué, Colombia;

* Corresponding author: paulaxvb@ut.edu.co

\section{INTRODUCTION}

Mango is widely produced in the tropical and subtropical regions of the world. It is classified in the fifth position among the main fruits, and it is cultivated in more than 100 countries of the world (Nadeem et al. 2016). Mango is one of the most widely consumed and commercialized fruits in the world (Oliveira et al. 2016), with a production of approximately 33 million tons (t). In 2017, Colombia produced 280.605 tons of mango (Agronet 2020). In Colombia there are 16 varieties of mango that can be grouped in creole and improved varieties. Común, Manzano, and Mariquiteño varieties are creole. Yulima is an improved variety. These varieties are the most cultivated in the Department of Tolima. This region is positioned as the largest producer in the country, contributing $28.95 \%$, which makes this region an important production area for this crop in the country. Mango fruits are processed for products such as puree, nectar, leather, canned slice and chutney, juices, ice cream, fruit bard, and pies (Yatnatti et al. 2014).

During the mango production there is a significant percentage of loss linked to three different periods in the distribution chain: agricultural and postharvest production, storage, and industrial processing (Departamento Nacional de Planeación 2016). A minimum of $15 \%$ loss in terms of quality has been estimated, but in periods of high harvest and low 
prices, producers experience losses of up to $40 \%$ (Fedemango 2017). It has been estimated that global mango production for 2017 reached 47.1 million tons (FAO 2017), and its processing generates between 25 and $40 \%$ in losses (Banerjee 2016). During industrial processing most of the biological waste generated from the conversion of raw mango into processed products is associated with the seeds (Dorta et al. 2012). The mango seed kernel represents 45 to $75 \%$ of this waste, and more than a million tons of seeds are wasted (Leanpolchareanchai et al. 2014).

The elimination of mango seed is increasingly difficult, and their disposal is linked to environmental problems (Dorta et al. 2012). Mango seed could have valuable compounds that can be exploited by applying new waste recovery strategies (FernandezPonce 2015). It has been proposed that biorefineries could be used as a viable alternative to generate value-added products from biomass used as a raw material, which would prevent loss or the underutilization of the waste (Arora et al. 2018). Furthermore, considering that this alternative poses a continuous recovery cycle, it could be proposed as the next step in the mango production system.

Several studies have shown that it is possible to recover compounds with antioxidant, antimicrobial, and antifungal properties from mango seed (Rajan et al. 2012; Subbiya et al. 2013; Maisuthisakul and Gordon 2014; Dorta et al. 2015; Hoyos-Arbeláez et al. 2018; Ballesteros-Vivas et al. 2019; Melo et al. 2019), which generates high hopes for the continued search for new drugs and bioactive components in the food, cosmetic, and pharmaceutical industry (Khammuang, S and Sarnthima, R. 201; Bolla.,2011).

The use and characterization of the seed varieties Común, Mariquiteño, Yulima, and Manzano varieties has never been evaluated in the region. Therefore, this study was carried out to characterize the chemical composition (fatty acids, phenolic compounds, flavonoids) and the in-vitro biological activities (antioxidant, antimicrobial, and growth induction of edible fungal strains) of mango seed of this varieties. This study proposes a use of this undervalued waste through biological alternatives.

\section{EXPERIMENTAL}

\section{Materials}

Four varieties of mango (Mangifera indica L.) were collected in the municipality of Espinal in the department of Tolima (Colombia): Yulima, Manzano, Mariquiteño, and Común. Pathogen-free fruits were selected during ripening stages 3 and 4 according to Colombian Institute of Technical Standards and Certification (ICONTEC, for its acronym in Spanish) standards 5210 (2003) and 5139 (2002).

\section{Collection and treatment of the material}

Seeds from ripe fruits were collected after separating from the pulp. The seeds were washed, cut longitudinally to separately obtain the endocarp and kernel. Endocarp and kernel were dried $\left(40{ }^{\circ} \mathrm{C}\right.$ for $\left.24 \mathrm{~h}\right)$ and ground to standardize the particle size in an electric mill into separate flours.

\section{Obtaining extracts}

The kernel flours $(50 \mathrm{~g})$ of the four varieties were extracted with $200 \mathrm{~mL}$ of $\mathrm{n}$ hexane in Soxhlet apparatus for $8 \mathrm{~h}$ obtaining hexanic extract (HE). The ethanolic extract (EE) was prepared from the extraction of kernel residues using ethanol in Soxhlet apparatus 
for $8 \mathrm{~h}$. The extracts obtained (HE and $\mathrm{EE}$ ) were evaporated and concentrated using a rotary vacuum evaporator to $45{ }^{\circ} \mathrm{C}$ (Büchi, Flawil, Sweden). The extracts were stored together with the extraction kernel waste (EKR) in a freezer at minus $85{ }^{\circ} \mathrm{C}$ (Kaltis 390 freezer) until use. The latter was used as a growth inducer for the edible fungal strains.

\section{Fatty acid composition}

A weight of $0.170 \mathrm{~g}$ of $\mathrm{HE}$ was taken for the isolated fatty acid mixture, and 4.0 $\mathrm{mL}$ of $\mathrm{NaOH}$ in methanol was added. The mixture was refluxed in a water bath at $90{ }^{\circ} \mathrm{C}$ for $7.0 \mathrm{~min}$; after this time $5.0 \mathrm{~mL}$ of boron trifluoride $\left(\mathrm{BF}_{3}\right)$ to $12 \%$ in methanol was added, and it was allowed to reflux for another two (2) min. Then $4.0 \mathrm{~mL}$ of HPLC grade heptane was added, and it was allowed to reflux for another (1) min. The solution was cooled, and $100.0 \mathrm{~mL}$ of saturated $\mathrm{NaCl}$ solution was added. The upper (organic) phase and sodium sulfate anhydrous were separated. The samples were subsequently injected into an Agilent ${ }^{\circledR} 6890$ brand gas chromatograph equipped with a flame ionization detector (FID), under the following chromatographic conditions: injector and a $50.0 \mathrm{~m}$ capillary column DB-23, internal diameter $0.25 \mathrm{~mm}$, film thickness $1.4 \mu \mathrm{m}$. A total of $1.0 \mu \mathrm{L}$ was injected in all cases; the injector temperature was $220^{\circ} \mathrm{C}$, the temperature of the detector was 240 ${ }^{\circ} \mathrm{C}$, the flow rate of the carrier gas $(\mathrm{H} 2)$ was $40.0 \mathrm{~cm} / \mathrm{s}$, with a column pressure of 23.04 psi. The gas mixture in the detector was: Hydrogen flow: $45 \mathrm{~mL} / \mathrm{min}$, air flow: $450 \mathrm{~mL} /$ min, was used as gas makeup $\left(\mathrm{N}_{2}\right)$ with a flow of $45 \mathrm{~mL} / \mathrm{min}$, a 50:1 split ratio was used in a ramp run temperature: Initial column temperature: $200^{\circ} \mathrm{C}$ (isothermal for $10 \mathrm{~min}$ ) the temperature rises to $220^{\circ} \mathrm{C}$ with a rate of $2.0^{\circ} \mathrm{C} / \mathrm{min}$ (isothermal for $4.0 \mathrm{~min}$ ).

\section{Antioxidant activity of the ethanolic extracts}

The antioxidant activity was tested by adopting an ABTS and DPPH assay (Braca et al. 2002; Marquina et al. 2008). The DPPH and ABTS scavenging activity were analyzed using a UV-VIS 96-well microplate reader (Multiskan ${ }^{\circledR}$ GO, Thermo Scientific, Vantaa, Finland). The results were expressed as inhibitory concentration value $\left(\mathrm{IC}_{50}\right)$, which is the concentration of the sample stabilizing the $\mathrm{DPPH}^{*}$ or $\mathrm{ABTS}^{*+}$ radicals by $50 \%$. Calibration curve was obtained using different concentrations $(0.0312$ to $1 \mu \mathrm{g} / \mathrm{mL}$ for DPPH and 0.0039 to $0.0625 \mu \mathrm{g} / \mathrm{mL}$ for ABTS) of Trolox (6-hydroxy-2,5,7,8-tetramethychroman-2carboxylic acid) as standard. All these methods were conducted in triplicate.

\section{Antimicrobial activity of the ethanolic extracts}

The microdilution method was performed and the following microorganisms were used for these experiments: Escherichia coli (ATCC25922), Staphylococcus aureus (ATCC29213), Rhizopus sp., and Fusarium sp. The antibacterial and antifungal activity assays were performed using the M7-A8 and M38-A2 methodologies, respectively, according to the Clinical and Laboratory Standards Institute (CLSI). The extracts were tested at the following concentrations: 2000, 1000, 500, 250, 125, 62.5, and $32 \mu \mathrm{g} / \mathrm{mL}$. Positive controls of $250 \mu \mathrm{g} / \mathrm{mL}$ oxytetracycline and $500 \mu \mathrm{g} / \mathrm{mL}$ ketoconazole were used. For the antibacterial activity, bacterial strains were cultured overnight at $37{ }^{\circ} \mathrm{C}$ on Brain Heart Infusion Nutritious broth and adjusted to a final concentration of $1 \times 108$ colony forming units $(\mathrm{CFU}) / \mathrm{mL}$ (0.5 nephelometric turbidity units - McFarland scale), and the optical density was measured after $0,6,18$, and $24 \mathrm{~h}$ of incubation at a wavelength of 460 nm. For the antifungal activity, pathogen (Rhizopus sp. and Fusarium sp.) spore suspensions were prepared at a concentration of $1 \times 10^{4}$ conidia/mL and the optical density was measured after $0,18,24,36,48$, and $72 \mathrm{~h}$ of incubation at wavelength of $595 \mathrm{~nm}$. The 
absorbance values (optical density-OD) were measured spectrophotometrically using a Multiskan ${ }^{\circledR}$ GO UV/VIS microplate reader (Thermo Scientific). Inhibition percentages (\% INH) were calculated using Eq. 1,

$$
\% \text { INH }=\frac{\text { ODC }- \text { ODT }}{\text { ODC }} \times 100
$$

where ODC is the optical density of the control, ODT is the optical density of the treatment, and $\%$ INH is the percentage of inhibition.

\section{Chromatographic analysis of the phenolic composition}

The phenolic composition of the kernel EE from the four varieties was determined by UPLC chromatography. The UPLC chromatographic analysis was performed in the ACQUITY UPLCTM instrument (Waters, Milford, MA, USA) coupled with an ACQUITY UPLCTM PDA diode array detector and an ACQUITY UPLCTM FLR fluorescence detector according to the methodology described by Delpino-rius et al. (2015). The standard curve was prepared from a mixture of procyanidin B1, procyanidin $\mathrm{B} 2$, epicatechin, hyperoside, rutin, isoquercitrin, and quercitrin $(0.05 \mu \mathrm{g} / \mathrm{mL}, 0.1 \mu \mathrm{g} / \mathrm{mL}, 1$ $\mu \mathrm{g} / \mathrm{mL}, 5 \mu \mathrm{g} / \mathrm{mL}$, and $10 \mu \mathrm{g} / \mathrm{mL}$, respectively).

\section{Quantification of phenolic compounds and flavonoids}

The kernel flours $(500 \mathrm{mg})$ of the four varieties were extracted with $7.5 \mathrm{~mL}$ of acetone:water (6:4) solution in maceration for $2 \mathrm{~h}$. Acetone was allowed to evaporate for half an hour and centrifuged at $11.000 \mathrm{rpm}$ for $15 \mathrm{~min}$. After centrifugation, an aliquot of the supernatant was mixed with methanol $(5 \mathrm{~mL})$ to obtain the extracts. The quantification of the phenolic compounds and flavonoids was determined according to the methodology described by Rodriguez et al. (2012) with some modifications. Solutions of gallic acid (Sigma-Aldrich®) (25 to $800 \mu \mathrm{g} / \mathrm{mL})$ and quercetin $(2.5$ to $30 \mu \mathrm{g} / \mathrm{mL}$ ) were used to construct the calibration curves. The results were expressed as milligram equivalents of gallic acid/gram of dry material (mg GAE/g) and milligrams of quercetin/g of dry material (mg QE/g).

\section{Growth of edible fungi in mango seed waste}

The mycelia growth of Lentinus crinitus (L.) Fr. and Pleurotus tubarius (Pat.) Peglers were evaluated in different treatments with mango endocarp (ME) and extraction kernel residues (KR). Five culture media agars (ME Yulima-T1, ME Manzano-T2, ME Mariquiteño-T3, ME Común-T4 and extraction kernel residues-T5) were use. Fungi mycelial growth was tested in Petri dishes following the methodology proposed by Martínez et al. (2015). The ME and KR were used for determination of proximate analysis and mineral element composition according to AOAC (1995). Person correlation analysis was performed between the growth rate and the variables of the proximal and mineral composition.

\section{Statistical analysis}

ANOVA was performed for each calculation, and the means with their respective standard deviations (SD) are presented in tables. When there were significant differences between the means of each treatment $(\mathrm{P}<0.05)$, the Fisher's least significant difference (LSD) a posteriori test was performed. To analyze the mycelial growth of edible fungi due to each treatment, the rate of growth of each treatment was evaluated and the significant 
differences between the treatments were checked. These analyzes were performed using the R-study program.

\section{RESULTS AND DISCUSSION}

Table 1 presents the fatty acid profiles of the four mango seed varieties. Oleic and stearic acid are shown in higher proportion. Yulima, Manzano, and Mariquiteño varieties showed values of oleic acid of $44.73,46.1$, and $44.78 \%$, respectively, followed by stearic acid with values of $40.4,39.74$, and $38.0 \%$, respectively. The Común variety presented a different proportion with a higher stearic acid content of $44.70 \%$ and a lower percentage of oleic acid, at $41.51 \%$. Palmitic, linoleic, and linolenic acids were found in lower percentages in all the mango varieties. These results can be compared with the reports by Mariod et al. (2017).

Table 1. Relative Composition of Fatty Acids Derived from the Mangifera indica Seed Kernel

\begin{tabular}{|c|c|c|c|c|}
\hline Fatty Acids (\%) & Yulima & Manzano & Mariquiteño & Común \\
\hline Lauric & $\begin{array}{c}0.00646 \pm \\
0.00009\end{array}$ & $\begin{array}{c}0.0033 \pm \\
0.0005\end{array}$ & $\begin{array}{c}0.00552 \pm \\
0.00005\end{array}$ & $\begin{array}{c}0.00453 \pm \\
0.00001\end{array}$ \\
\hline Myristic & $0.025 \pm 0.001$ & $0.023 \pm 0.003$ & $0.034 \pm 0.006$ & $0.022 \pm 0.002$ \\
\hline Palmitic & $6.385 \pm 0.005$ & $6.643 \pm 0.003$ & $7.7 \pm 0.2$ & $5.720 \pm 0.004$ \\
\hline Stearic & $40.395 \pm 0.009$ & $\begin{array}{c}39.7338 \pm \\
0.0006\end{array}$ & $38.0 \pm 0.2$ & $44.70 \pm 0.07$ \\
\hline Oleic & $\begin{array}{c}44.7214 \pm \\
0.0006\end{array}$ & $46.11 \pm 0.02$ & $44.78 \pm 0.07$ & $41.51 \pm 0.06$ \\
\hline Linoleic & $3.682 \pm 0.003$ & $\begin{array}{c}3.4518 \pm \\
0.0002\end{array}$ & $5.70 \pm 0.07$ & $3.92 \pm 0.01$ \\
\hline Linolenic acid & $\begin{array}{c}0.4184 \pm \\
0.0006\end{array}$ & $\begin{array}{c}0.2385 \pm \\
0.0008\end{array}$ & $0.306 \pm 0.006$ & $0.304 \pm 0.004$ \\
\hline EPA $^{a}$ & $0.501 \pm 0.001$ & $0.402 \pm 0.002$ & $0.3782 \pm 0.0009$ & $0.447 \pm 0.002$ \\
\hline $\mathrm{DHA}^{\mathrm{b}}$ & $\begin{array}{c}0.00916 \pm \\
0.00006\end{array}$ & $\begin{array}{c}0.0078 \pm \\
0.0002\end{array}$ & - & - \\
\hline
\end{tabular}

The most used active ingredients in cosmetics are oils from seeds that are rich in unsaturated fatty acids (Alcalde 2007), indicating that fatty acids in mango can be used for different applications, including food. For example, Kittiphoom (2012) and Jahurul et al. (2014) report that mixtures (80:20) of mango lard and palm stearin could be used to produce butter resistant to hot climates and be used as a substitute for cocoa butter. Beyond the food industry, in the cosmetics industry, there is great demand for ingredients in soaps, moisturizing creams, lubricants, hair softeners and formulations for lipstick and phytomilk (Méndez Arteaga et al. 2013).

\section{Phenol, Flavonoid, and Procyanidin B1 Contents}

The total phenolics contents detected in the four mango variety seed varieties are shown in Table 2. The highest values were detected in Yulima and for the other varieties the contents were statistically similar with values from 103 to $110 \mathrm{mg} \mathrm{GAE} / \mathrm{g}$. The four varieties evaluated had higher phenolic contents than those found in other studies with 
cultured mangoes of different origins (Adilah et al. 2018; Melo 2019; Castro-Vargas et al. 2019). However, compared with other reports, the present values are considered much lower because they have up to two-, three-, and fourfold more phenolic contents than previously studied varieties (Khammuang and Sarnthima 2011; Sogi et al. 2013; Dorta et al. 2014; Patiño-Rodriguez 2019). These variations can be attributed to factors such as genetic characteristics, environment, maturity stage, and agricultural practices (TorresLeón et al. 2016).

Table 2. Content of Phenolics, Flavonoids, Procyanidin B1 Compounds and Antioxidant Activity of Ethanolic Extracts

\begin{tabular}{|c|c|c|c|c|c|}
\hline \multirow{2}{*}{$\begin{array}{l}\text { Mango } \\
\text { variety }\end{array}$} & \multirow{2}{*}{$\begin{array}{c}\text { Total } \\
\text { phenolics } \\
\text { content }^{\mathrm{a}}\end{array}$} & \multirow{2}{*}{$\begin{array}{c}\text { Total } \\
\text { flavonoid } \\
\text { content }\end{array}$} & \multirow{2}{*}{$\begin{array}{c}\text { Procyanidin } \\
\text { B1 } \\
(\mu \mathrm{g} / \mathrm{g})\end{array}$} & \multicolumn{2}{|c|}{$\begin{array}{c}\text { Antioxidant activity (IC50 } \\
\mu \mathrm{g} / \mathrm{mL} \text { ) }\end{array}$} \\
\hline & & & & ABTS•+ & DPPH・ \\
\hline Yulima & $125 \pm 2.1 \mathrm{a}$ & $0.8 \pm 0.04$ & $\begin{array}{c}0.407 \pm \\
0.0058 \mathrm{c}\end{array}$ & 3.4 & 13.9 \\
\hline Manzano & $110 \pm 4.6 b$ & $0.8 \pm 0.02$ & $\begin{array}{c}0.152 \pm \\
0.0402 b\end{array}$ & 3.4 & 13.0 \\
\hline Mariquiteño & $103 \pm 8.3 b$ & $0.77 \pm 0.2$ & $\begin{array}{c}0.065 \pm \\
0.0024 \mathrm{a}\end{array}$ & 3.4 & 12.2 \\
\hline Común & $107 \pm 8.2 b$ & $0.72 \pm 0.07$ & $\begin{array}{c}0.146 \pm \\
0.01900 \mathrm{~b}\end{array}$ & 3.1 & 12.2 \\
\hline
\end{tabular}

The flavonoid contents of each of the varieties was similar, with values ranging from 0.72 to $0.8 \mathrm{mg} \mathrm{QE} / \mathrm{g}$ dry weight. In contrast, Dorta et al. (2014) compared different mango varieties with respect to their flavonoid contents and found minimal differences for the Gomera, Keitt, and Sensation varieties which had flavonoid contents of 0.72, 0.95, and $1.17 \mathrm{mg} \mathrm{CE} / 100 \mathrm{~g}$ dry weight, respectively.

Despite the high phenol contents found in the tested samples, the results suggest that flavonoids constitute a minimal proportion of these compounds. However, flavonoids are associated with a broad spectrum of health-promoting effects and are indispensable components in a variety of nutraceutical, pharmaceutical, medicinal and cosmetic applications. This is attributed to their antioxidant, anti-inflammatory, antimutagenic and anticarcinogenic properties, together with their ability to modulate cellular enzyme function (Panche et al. 2016).

The chromatographic profiles of the Mangifera indica seed ethanolic extracts were very similar in composition. Thus, it was possible to identify signals at the retention times (RTs) ranging from $7.99 \mathrm{~min}$ to $16.10 \mathrm{~min}$. This was in contrast to the patterns observed in the UV and fluorescence spectra. These data made it possible to characterize flavan-3-oles as the main family of phenols.

Within this family, procyanidin B1 is reported for the first time in the mango kernel of the studied varieties, which is contrast to previous reports showing that it was limited to mango pulp (Rue et al. 2017). Procyanidins are condensed flavan-3-ols that constitute an important group of polyphenols due to their bioactivity. Procyanidin B1 shows chemopreventive potential against cancer (Lee 2017), antioxidant activity (Muselík et al. 2007) and anti-inflammatory (Xing et al. 2015), antidiabetic (Gonzalez-Abuin et al. 2015) 
and antiviral (Li et al. 2010) properties. Given its presence in the kernel of the four varieties studied, the potential of this byproduct stands out in terms of the integrative use of the fruit.

\section{Bioactivity of Ethanolic Extracts from Mango Seed}

The ethanolic extracts derived from the seeds of the four varieties showed antiradical activity against $\mathrm{ABTS}^{\circ+}$ and $\mathrm{DPPH}^{\bullet}$ at low concentrations (Table 2 ). The $\mathrm{IC}_{50}$ ranged from 3.1 to $3.4 \mu \mathrm{g} / \mathrm{mL}$ against $\mathrm{ABTS}^{\circ+}$ and between 12.2 and $13.9 \mu \mathrm{g} / \mathrm{mL}$ against $\mathrm{DPPH}^{\circ}$, reflecting the similarity between the varieties. There are reports supporting that there exists a relation between the phenol contents and antioxidant potential of extracts of plants (Hossain et al. 2014; Das et al. 2015; Khanal et al. 2015), which would explain the remarkable antioxidant capacity of the four varieties given their high phenol contents. The mango seed ethanolic extract is among the top four of 100 extracts evaluated with regard to its antioxidant capacity (Torres-León et al. 2016).

Additionally, the results from the first method ( $\mathrm{IC}_{50}: 3.1$ to $3.4 \mu \mathrm{g} / \mathrm{mL}$ ) are consistent with the results of the method proposed by Nakpanich et al. (2017) for the Mangifera indica seed methanolic extract, which presented an $\mathrm{IC}_{50}$ of $3.4 \mu \mathrm{g} / \mathrm{mL}$. Similarly, Khammuang and Sarnthima (2011) report ethanolic extract values of 4.13 and $4.8 \mu \mathrm{g} / \mathrm{mL}$ for the Chok-a-nan and Nam-dok-mai varieties, respectively, which come from a common area.

The antimicrobial potential of the extracts was also evaluated. The supplementary information shows the inhibition percentages generated by the ethanolic extracts of the four varieties against the microorganisms tested. In the case of the Yulima variety, inhibition percentages greater than $50 \%$ were generated against $S$. aureus at the lowest concentration evaluated and against E. coli and Rhizopus sp. at concentrations greater than $250 \mu \mathrm{g} / \mathrm{mL}$. In contrast, the Manzano, Común and Mariquiteño varieties showed inhibition percentages greater than $50 \%$ against $S$. aureus and Rhizopus sp.

The results obtained can be compared with those other studies in which extracts with different mango kernel polarities and their antimicrobial activity have been used. For example, Abdalla et al. (2007) showed that the mango kernel methanolic extract inhibited $E$. coli growth at a concentration of $400 \mu \mathrm{g} / \mathrm{mL}$. The mango kernel methanolic extract has been reported to inhibit a wide range of microorganisms at a concentration of $200 \mu \mathrm{g} / \mathrm{mL}$ (Engels et al. 2011), which is consistent with the results obtained in this study, specifically for $S$. aureus, at concentrations between 125 and $250 \mu \mathrm{g} / \mathrm{mL}$. As stated by Vaghasiya et al. (2011), the presence of elevated levels of tannins and phenolic compounds in the extract could promote antimicrobial bioactivities. The phenol contents may play an important role in antimicrobial activity; however, it is necessary to predict with certainty which group of metabolites is generating this activity.

Some authors, such as Shabani and Sayadi (2014), have reported a concentration of $25 \mu \mathrm{g} / \mathrm{mL}$ to inhibit important bacteria such as Salmonella enteritidis, Klebsiella aerogenes, and E. coli, among others. Kabuki (2000) reported inhibition of E. coli at 2500 $\mu \mathrm{g} / \mathrm{mL}$. By contrasting these results with those obtained in this study, it can be predicted that the ethanolic extracts obtained from the mango kernel have an interesting potential to inhibit this type of microorganism at concentrations lower than those previously reported.

Related to the percentages of inhibition against Rhizopus sp. (supplementary information), it was found that all of the extracts inhibited Rhizopus sp. between 87 and $89.6 \%$ at a concentration of $1000 \mu \mathrm{g} / \mathrm{mL}$, with a dose-response effect. Few studies have evaluated mango seed for this biological activity; among them, Dorta et al. (2016) reported minimum inhibitory concentrations (MICs) for the three mango cultivars as a function of 
the total phenol concentration in the extract. These authors determined MICs from 0.1 to 5 $\mathrm{mg}$ GAE/mL against 17 fungi, demonstrating that there is a relationship between the phenolic composition (high levels of proanthocyanidins, gallates and gallotannins), antifungal activity and the ability to inhibit lipid peroxidation. Among the few reports on the antifungal activity of mango kernel extracts, none emphasize the organisms used in the present study; therefore, the results found here are the first to report antifungal activity by the ethanolic extracts obtained from the seeds of mango varieties.

\section{Extraction Kernel Waste as a Substrate for the Growth of Edible Fungi}

Mango waste from the varieties under study has been explored in their various forms in the recovery of important metabolites. However, this study examined the viability of seed flour (press cake) and the endocarp as a substrate for the mycelial growth of edible fungi. This alternative was proposed given that mushrooms can colonize a wide variety of lignocellulosic substrates (Martínez et al. 2015b; Coello-Loor et al. 2017; Dávila et al. 2020). Table 3 shows the growth rate of two strains on extraction kernel waste of mango. It was observed that all wastes induced the growth of edible strains, and in some cases the growth rate was higher than that of the potato dextrose agar (PDA) basal medium.

Table 3. Mycelial Growth of Edible Fungi on Mango Waste

\begin{tabular}{|l|l|l|}
\hline \multirow{2}{*}{ Treatment } & Growth Rate (GR) (cm/day) \\
\cline { 2 - 3 } & Lentinus crinitus & Pleurotus tubarius \\
\hline T1(Yulima) & $1.38 \pm 0.072 \mathrm{a}$ & $1.71 \pm 0.15 \mathrm{~b}$ \\
\hline T2 (Manzano) & $1.39 \pm 0.036 \mathrm{a}$ & $1.52 \pm 0.074 \mathrm{c}$ \\
\hline T3 (Mariquiteño) & $1.19 \pm 0.086 \mathrm{~b}$ & $1.38 \pm 0.072 \mathrm{~d}$ \\
\hline T4 (Común) & $1.41 \pm 0.058 \mathrm{a}$ & $1.59 \pm 0.056 \mathrm{bc}$ \\
\hline T5 (PC) & $0.32 \pm 0.014 \mathrm{c}$ & $1.68 \pm 0.13 \mathrm{bc}$ \\
\hline (Control) PDA & $1.17 \pm 0.029 \mathrm{~b}$ & $1.71 \pm 0.09 \mathrm{ab}$ \\
\hline
\end{tabular}

Each value is expressed as the mean \pm SD $(n=3)$ (ANOVA $p<0.05)$. T5 extraction kernel waste: Mango seed flour remaining after extraction. Means with different letters represent significant differences between varieties $(p<0.05)$ with Fisher's least significant difference (LSD) test.

Mycelial growth varied depending on the treatment used, with the waste of the Común variety inducing the fastest growth of L. crinitus and the Yulima waste inducing the greatest growth by $P$. tubarius.

These differences may be due to the composition of the waste, as observed in Fig. 1, which shows the correlation between the composition of the medium and the growth rate. This figure indicates the Pearson product correlations between each pair of variables. The range of these correlation coefficients is from -1 to +1 , which measures the strength of the linear relationship between the variables represented in red to yellow. Additionally, the figures show, in circles, only those variables that presented a correlation with $\mathrm{p}$ values less than 0.05 .

In this sense, the growth rate of $P$. tubarius is negatively related to the protein, phosphorus, ash, and nitrogen contents and positively related to the fiber, calcium and sodium contents. For L c crinitus, mycelial growth is positively related to the iron content. However, it should be clarified that there are other factors that may influence the growth of edible fungus strains. 

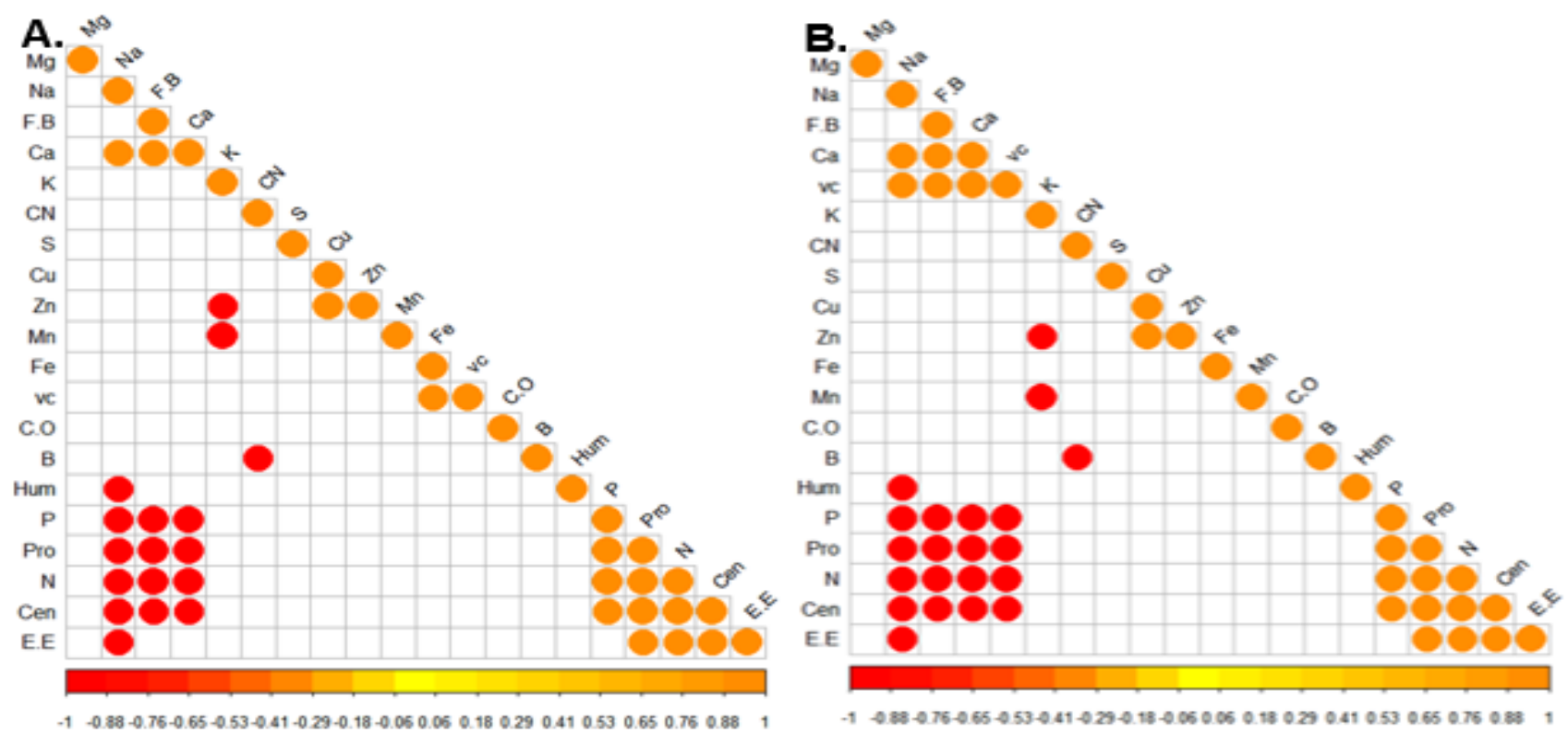

Fig. 1. A and B. Correlation matrix of the Pearson between wastes remaining composition variables and growth rate of $L$. crinitus and $P$. tubarius, respectively. Light orange color indicates positive relation of the variables, red-inverse correlation. Only significant correlations are filled with color and circles (confidence $=0.95$ ).

Hum: Humidity (\%), Ash: ash\%), Pro: Protein (\%), EE: Ethereal extract (\%), FB: Crude fiber (\%), CO: Organic carbon (\%), N: Nitrogen (\%), Ca: Calcium (\%), Na: Sodium (mg/kg), K: potassium (\%), Mg: Magnesium, Cu: Copper (mg/kg), Zn: Zinc (mg/kg), Fe: Iron (mg/kg), Mn: Manganese $(\mathrm{mg} / \mathrm{kg})$, B: boron (mg/kg), P: phosphorus (\%) and S: Sulfur (\%).

This type of test is important to select the best waste or combination of wastes to process these wastes into other value-added products, such as the production of basidioma for human consumption (Motato et al. 2006; Martínez et al. 2015; Oviedo et al. 2016) or other products of general interest, including waste pressed into cakes with the fungus as soil improvers or as animal feed (Hanafi Fatimah et al. 2018).

The use described in this research is performed in an integrated manner, as summarized in Fig. 2, where the system processes the seed product wastes (kernel and endocarp) of the four varieties. The flour serves as a source of metabolites of interest, including fatty acids and phenolic compounds, the latter of which has important bioactivity, such as antioxidant and antimicrobial activities. Moreover, the fatty acids present in the wastes have a similar composition to cocoa seed fats, which are used in the food and cosmetic industry. This potentiates the use of mango fatty acids in these fields because they could be even more economical to obtain. Additionally, the waste in the press cake and the remaining endocarps were used as substrates for the growth of edible fungi, which can colonize this type of substrate for the production of basidioma for human consumption or the material biodegraded by the fungus, as compost or animal feed. This system could be used for the creation of a collection center for this type of waste material whose similarity in composition and bioactivity would not involve its separation. Consequently, an addedvalue chain could be generated that could benefit the producer and reduce environmental problems due to waste disposal. This research provides information for management alternatives and for the final disposal of mango seeds, especially varieties that are found in the region with a variety of bioactivities and compositions that generate value-added products. 


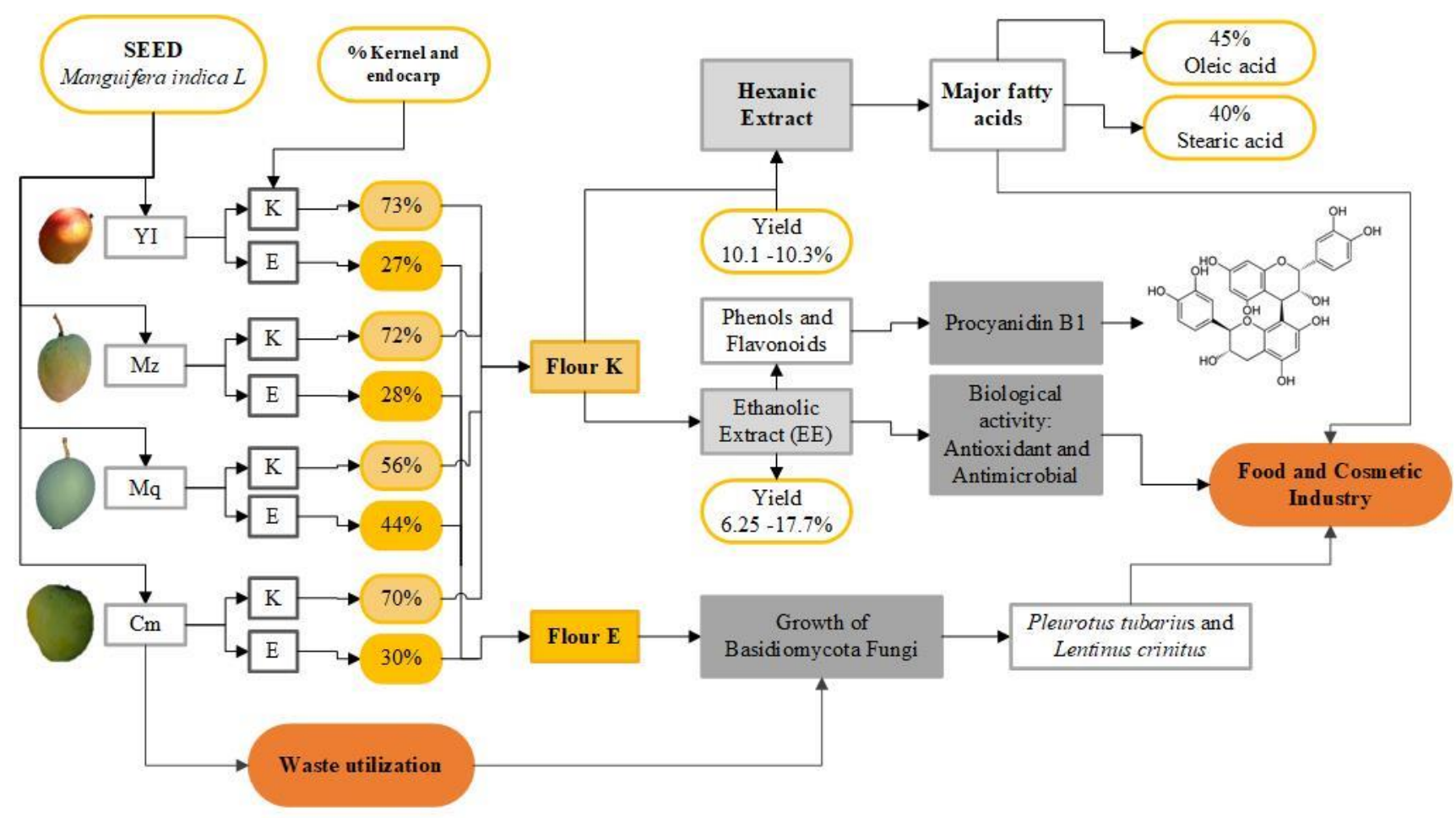

Seed kernel:K; Endocarp: E; Mariquiteño (Mq), Manzano (Mz), Comín (Cm) and Yulima (Yl)

Fig. 2. Flow chart on the characterization and use of mango seeds from four varieties cultivated in the Department of Tolima, Colombia

\section{CONCLUSIONS}

This research reports the characterization of the mango seed and its potential as source of bioactive compounds as the high phenolic compounds and unsaturated fatty acid contents. The presence of procyanidin B1 was identified for the first time. The antioxidant and antimicrobial activity of ethanol extracts is highlighted.

The use of mango seed as an inducer of fungal growth provides alternative uses and benefits of the waste generated from these mango varieties, which has not been studied extensively. This opens a door to generate more studies of this kind where the generation of alternative income to mango growers and economic feasibility can be verified.

\section{ACKNOWLEDGMENTS}

The authors acknowledge the financial support provided by the Research Office of the University of Tolima; Mr. José Joaquin and Angela Medina, who, with their great kindness, provided us with the plant materials from their farms; and the LASEREX and GIPRONUT research group for their enormous support in providing the spaces and materials. 


\section{REFERENCES CITED}

Abdalla, A. E. M., Darwish, S. M., Ayad, E. H. E., and El-Hamahmy, R. M. (2007). "Egyptian mango by-product 2: Antioxidant and antimicrobial activities of extract and oil from mango seed kernel." J. Food Chemistry, 103(4), 1141-1152. DOI: 10.1016/j.foodchem.2006.10.017

Adilah, A. Nor, Jamilah, B., Noranizan, M., \& Hanani, Z. Nur. (2018). Utilization of mango peel extracts on the biodegradable films for active packaging. Food packaging and shelf life, 16, 1-7. doi: 10.1016/j.fpsl.2018.01.006

Agronet. (2020). "Evaluaciones agropecuarias municipales" (http://www.agronet.gov.co/Paginas/ProduccionNacionalDpto.aspx), Consultado el 19 de enero del 2020

Alcalde, M. T. (2007). "Alimentos usados en formulación cosmética. Propiedades y aplicaciones." Offarm, 26(3), 100-109.

AOAC (1995) Métodos oficiales de análisis. 16ª Edición, Asociación de Químicos Analíticos Oficiales, Washington DC.

Arora, A., Banerjee, J., Vijayaraghavan, R., MacFarlane, D., \& Patti, A. F. (2018). "Process design and techno-economic analysis of an integrated mango processing waste biorefinery." Industrial Crops and Products, 116, 24-34. DOI: 10.1016/j.indcrop.2018.02.061

Ballesteros-Vivas, D., Álvarez-Rivera, G., Morantes, S. J., Sánchez-Camargo, A. del P., Ibáñez, E., Parada-Alfonso, F., and Cifuentes, A. (2019). "An integrated approach for the valorization of mango seed kernel: Efficient extraction solvent selection, phytochemical profiling and antiproliferative activity assessment." Food Research International, Elsevier, 126(August), 108616. DOI: /10.1016/j.foodres.2019.108616

Banerjee, J. (2016). "Effect Of Drying Methods And Extraction Time-Temperature Regime On Mango Kernel Lipids." International Journal of Food and Nutritional Science, 3(2), 1-10. DOI: 10.15436/2377-0619.16.048.

Bolla, J., Alibert-franco, S., Handzlik, J., Chevalier, J., Mahamoud, A., Boyer, G., Kiéckononowicz, K., and Pages, J. (2011). "Strategies for bypassing the membrane barrier in multidrug resistant Gram-negative bacteria." Federation of European Biochemical Societies, 585, 1682-1690. DOI: 10.1016/j.febslet.2011.04.054

Braca, A., Sortino, C., Politi, M., Morelli, I., and Mendez, J. (2002). "Antioxidant activity of flavonoids from Licania licaniaeflora.” Journal of ethnopharmacology, Journal Article, Ireland, 79(3), 379-381. DOI: 10.1016/s0378-8741(01)00413-5

Castro-Vargas, H. I., Ballesteros Vivas, D., Ortega Barbosa, J., Morantes Medina, S. J., Aristizabal Gutiérrez, F., \& Parada-Alfonso, F. (2019). "Bioactive phenolic compounds from the agroindustrial waste of Colombian mango cultivars 'Sugar Mango' and 'Tommy Atkins'-An alternative for their use and valorization," Antioxidants, 8(2), 41. DOI:10.3390/antiox 8020041

CLSI M38-A2. (2008) "Reference method for broth dilution antifungal susceptibility testing of filamentous fungi," Clinical and Laboratory Standards Institute, Wayne, Pennsylvania, USA.

CLSI M7-A8. (2009) "Methods for dilution antimicrobial susceptibility tests for bacteria that grow aerobically," Clinical and Laboratory Standards Institute, Wayne, Pennsylvania, USA.

Coello-Loor, C., Avellaneda, J., Barrera, A., Peña, M. M., Yépez, P., and Racines, E. (2017). "Evaluación del crecimiento y producción de biomasa de dos cepas del 
género." Ciencia y Tecnología, 10(2), 33-39. DOI: /10.18779/cyt.v10i2.164

Das, S., Alam, M. D. N., Batuta, S., Roy, N., and Begum, N. A. (2015). "Exploring Comparative Antioxidant Activity of Some Popular Cultivars of Mangifera indica L., National Fruit of India." International Journal of Fruit Science, 15(2), 129-147. DOI: $10.1080 / 15538362.2014 .954509$

Dávila G, L. R., Murillo A, W., Zambrano F, C. J., Suárez M, H., and Méndez A, J. J. (2020). "Evaluation of nutritional values of wild mushrooms and spent substrate of Lentinus crinitus (L.) Fr." Heliyon 6(3), 0-4.

Delpino-rius, A., Eras, J., Vilaró, F., Angel, M., Balcells, M., and Canela-Garayao, R. (2015). "Characterisation of phenolic compounds in processed fibres from the juice industry." Food Chemistry, 172, 575-584. DOI: 10.1016/j.foodchem.2014.09.071

Departameto Nacional de Planeación. (2016). "Estudio perdida y desperdicios de Colombia"(https://mrv.dnp.gov.co//Documentos\%20de\%20Interes/Perdida_y_Desp erdicio_de_Alimentos_en_colombia.pdf), Consultado el 10 de septiembre del 2019.

Dorta, E., González, M., Lobo, M. G., and Laich, F. (2016). "Antifungal activity of mango peel and seed extracts against clinically pathogenic and food spoilage yeasts." Natural Product Research, Taylor \& Francis, 30(22), 2598-2604. DOI: 10.1080/14786419.2015.1115995

Dorta, E., González, M., Lobo, M. G., Sánchez-Moreno, C., and de Ancos, B. (2014). "Screening of phenolic compounds in by-product extracts from mangoes (Mangifera indica L.) by HPLC-ESI-QTOF-MS and multivariate analysis for use as a food ingredient." Food Research International, Elsevier Ltd, 57, 51-60. DOI: 10.1016/j.foodres.2014.01.012

Dorta, E., Lobo, M. G., and Gonzalez, M. (2012). "Reutilization of mango byproducts: Study of the effect of extraction solvent and temperature on their antioxidant properties." J. Food Chemistry, 77(1), 80-88. DOI: 10.1111/j.17503841.2011.02477.x

Dua, A., Agrawal, S., Singh, A., and Mahajan, R. (2016). "Antioxidant and Antimicrobial Potential of Polyphenols from Foods," in: Microbes in Food and Health, 43-63. Garg N., Abdel-Aziz S., Aeron A. (eds), Switzerland.

Engels, C., Schieber, A., and Gänzle, M. G. (2011). "Inhibitory spectra and modes of antimicrobial action of gallotannins from mango kernels (Mangifera indica L.)." Applied and Environmental Microbiology, 77(7), 2215-2223. DOI: 10.1128/AEM.02521-10

FAO. (2017). "Perspectivas mundiales de las principales frutas tropicales" (http://www.fao.org/fileadmin/templates/est/COMM_MARKETS_MONITORING/ Tropical_Fruits/Documents/Tropical_Fruits_Spanish2017.pdf), accessed 20 October 2019

Fedemango., L. 1. (08 de Agosto de 2017). Pérdida del mango . (P. X. B., Entrevistador)

Fernandez-Ponce, M. T. (2015). "Use of high pressure techniques to produce Mangifera indica L . leaf." Innovative Food Science and Emerging Technologies, Elsevier B.V., 1-40. DOI: 10.1016/j.ifset.2015.04.006

Gonzalez-Abuin, N., Pinent, M., Casanova-Marti, A., Arola, L., Blay, M., and Ardevol, A. (2015). "Procyanidins and their healthy protective effects against type 2 diabetes." Current Medicinal Chemistry, 22(1), 39-50.

Hanafi, F. H., Rezania, S., Mat Taib, S., Md Din, M. F., Yamauchi, M., Sakamoto, M., Hara, H., Park, J., \& Ebrahimi, S. S. (2018). "Environmentally sustainable applications of agro-based spent mushroom substrate (SMS): an overview." Journal 
of Material Cycles and Waste Management, 20(3), 1383-1396. DOI:

10.1007/s10163-018-0739-0

Hossain, S. J., Sultana, S., Taleb, M. A., Basar, M. H., Sarower, M. G., \& Hossain, A. (2014). "Antioxidant activity of ethanol and lipophilic extracts of common fruity vegetables in Bangladesh," International Journal of Food Properties, 17(9), 20892099. DOI: 10.1080/10942912.2013.790052Hoyos-Arbeláez, J., Blandón-Naranjo, L., Vázquez, M., and Contreras-Calderón, J. (2018). “Antioxidant capacity of mango fruit (Mangifera indica). An electrochemical study as an approach to the spectrophotometric methods.” Food Chemistry, Elsevier, 266, 435-440. DOI: 10.1016/j.foodchem.2018.06.044

Hyum, U. I. (2014). "Cosmetic composition for anti-irritation and hydration of the skin containing Citrus junos Siebold seed oil and Mangifera Indica seed oil," South Korea. Patent No. 101425031

Icontec. (2003). "NTC-5210 para frutas frescas, mango, variedades mejoradas, especificaciones para cultivares mejoradas," Instituto Colombiano de Normas Técnicas y Especificaciones, Bogotá, Colombia

Icontec. (2002). "NTC-5139 para frutas frescas, mangos criollos, especificaciones," Instituto Colombiano de Normas Técnicas y Especificaciones, Bogotá, Colombia

Jahurul, M. H. A., Zaidul, I. S. M., Nik Norulaini, N. A., Sahena, F., Kamaruzzaman, B. Y., Ghafoor, K., \& Omar, A. K. M. (2014). "Cocoa butter replacers from blends of mango seed fat extracted by supercritical carbon dioxide and palm stearin." Food Research International, 65, 401-406. DOI: 10.1016/j.foodres.2014.06.039

Joong, K. A. (2015). "Cosmetic Composition Comprising Mangifera indica L. Extract, Passiflora edulis Sims Extract, Hylocereus undatus (Haw.) Britt. and Rose Extract, Actinidia chinensis Planch. Extract and Annona Squamosa Extract ," South Korea. Patent No. 10-2015-0064314

Kabuki, T. (2000). "Characterization of novel antimicrobial compounds from mango (Mangifera indica L.) kernel seeds," Food Chemistry, 71(1), 61-66. DOI: 10.1016/S0308-8146(00)00126-6

Kaliora, A. C., Kogiannou, D. A. A., Kefalas, P., Papassideri, I. S., \& Kalogeropoulos, N. (2014). "Phenolic profiles and antioxidant and anticarcinogenic activities of Greek herbal infusions; Balancing delight and chemoprevention" Food Chemistry, 142, 233-241. DOI: 10.1016/j.foodchem.2013.07.056

Khammuang, S., \& Sarnthima, R. (2011). "Antioxidant and antibacterial activities of selected varieties of Thai mango seed extract," Pakistan Journal of Pharmaceutical Sciences, 24(1), 37-42.

Khanal, S., Shakya, N., Thapa, K., and Pant, D. R. (2015). "Phytochemical investigation of crude methanol extracts of different species of Swertia from Nepal." BMC

Research Notes, 8(1), 1-9. DOI: 10.1186/s13104-015-1753-0

Kittiphoom, S.. (2012). Utilization of mango seed. International Food Research Journal. 19. 1325-1335.

Leanpolchareanchai, J., Padois, K., Falson, F., Bavovada, R., and Pithayanukul, P. (2014). "Microemulsion System for Topical Delivery of Thai Mango Seed Kernel

Extract: Development, Physicochemical Characterisation and Ex Vivo Skin Permeation Studies." Molecules, 19, 17107-17129. DOI: 10.3390/molecules191117107

Lee, Y. (2017). "Cancer chemopreventive potential of procyanidin." Toxicological Research, 33(4), 273-282. DOI: 10.5487/TR.2017.33.4.27 
Li, S., Kodama, E. N., Inoue, Y., Tani, H., Matsuura, Y., Zhang, J., Tanaka, T., and Hattori, T. (2010). "Procyanidin B1 purified from Cinnamomi cortex suppresses hepatitis C virus replication." Antiviral Chemistry and Chemotherapy, 20(6), 239248. DOI: : 10.3851/IMP1597)

Maisuthisakul, P., and Gordon, M. H. (2014). "Characterization and storage stability of the extract of Thai mango (Mangifera indica Linn. Cultivar Chok-Anan) seed." $J$. Food Science and Technology, 51(8), 1453-1462. DOI: 10.1007/s13197-011-06049.

Mariod, A., Mirghani, M., and Hussein, I. (2017). Unconventional Oilseeds and Oil Sources, San Diego, Estados Unidos.

Maryam Adilah, Z. A., \& Nur Hanani, Z. A. (2019). "Storage stability of soy protein isolate films incorporated with mango kernel extract at different temperature." Food Hydrocolloids, 87, 541-549. DOI: 10.1016/j.foodhyd.2018.08.038

Marquina, V., Araujo, L., Ruíz, J., Rodríguez-Malaver, A., and Vit, P. (2008). "Composición química y capacidad antioxidante en fruta, pulpa y mermelada de guayaba (Psidium guajava L.).” Archivos Latinoamericanos de Nutricion, 58(1), 98102.

Martínez, D. A., Buglione, M. B., Filippi, M. V., Del, L., Reynoso, C., Rodríguez, G. E., and Agüero, M. S. (2015). "Evaluación del crecimiento micelial de Pleurotus ostreatus y Agrocybe aegerita sobre orujos de pera." Anales de Biología, 37, 1-10. DOI: 10.6018/analesbio.37.1

Melo, P. E. F., Silva, A. P. M., Marques, F. P., Ribeiro, P. R. V., Souza Filho, M. de sá M., Brito, E. S., Lima, J. R., and Azeredo, H. M. C. (2019). "Antioxidant films from mango kernel components.” Food Hydrocolloids, Elsevier Ltd, 95(May), 487-495. DOI: 10.1016/j.foodhyd.2019.04.061

Méndez Arteaga, J. J., Santofimio Varón, T., Robles Oviedo, C. J., Orjuela Garzón, W. A., Cardona, E. A., Agudelo Ramírez, D. F., \& Borras Reyes, L. E. (2013). Estudio de vigilancia tecnológica en frutos promisorios (mango, aguacate, café y chachafruto) para la industria cosmética y de aseo en el departamento del TolimaColombia, Universidad del Tolima, Ibague, Colombia.

Muselík, J., García-Alonso, M., Martín-López, M. P., Žemlička, M., and Rivas-Gonzalo, J. C. (2007). "Measurement of antioxidant activity of wine catechins, procyanidins, anthocyanins and pyranoanthocyanins." International Journal of Molecular Sciences, 8(8), 797-809.

Nakpanich, N., Chaiyana, W., and Leelapornpisid, P. (2017). "Antioxidant activities and stability of seed Kernel extracts from mango (Mangifera indica linn.) cultivated in Northern Thailand." Chiang Mai Journal of Science, 44(2), 573-583.

Nuñez, A., Paez, E. P., Gonzalez, Daniel A. Acosta, J., Aguero, J., Capote, R., Garciga, M., Morales, I., Garcia, O., Garrido, G., Martinez, G., and Morales, M. (2000). "Compositions obtained from Mangifera indica," Cuba. Patent No. 00/38699

Oliveira, B. G., Costa, H. B., Ventura, J. A., Kondratyuk, T. P., Barroso, M. E. S., Correia, R. M., Pimentel, E. F., Pinto, F. E., Endringer, D. C., and Romão, W. (2016). "Chemical profile of mango (Mangifera indica L.) using electrospray ionisation mass spectrometry (ESI-MS)." Food Chemistry, 204, 37-45. DOI: 10.1016/j.foodchem.2016.02.117

Oviedo, J. C., Casas, A. E., Valencia, J. A., \& García, L. (2016). "Evaluation of three variables of growth of pleurotus pulmonarius on corncob using digital image processing." Informacion Tecnologica, 27(5), 27-36. DOI: 10.4067/S0718- 
07642016000500004

Panche, A. N., Diwan, A. D., and Chandra, S. R. (2016). "Flavonoids: an overview." J. of Nutritional Science, 5(47), 1-15. DOI: 10.1017/jns.2016.41

Patiño-Rodríguez, O., Agama-Acevedo, E., Ramos-Lopez, G., \& Bello-Pérez, L. A. (2020). "Unripe mango kernel starch: Partial characterization." Food Hydrocolloids, 101(8). DOI: 10.1016/j.foodhyd.2019.105512

Rajan, S., Suganya, H., Thirunalasundari, T., and Jeeva, S. (2012). "Antidiarrhoeal efficacy of Mangifera indica seed kernel on Swiss albino mice." Asian Pacific Journal of Tropical Medicine, 5(8), 630-633. DOI: 10.1016/S19957645(12)601291.

Rodríguez, Y., Sánchez-Catalán, F., Rojano, B., Durango, D., Gil, J., and Marín-Loaiza, J. (2012). "Physicochemical characterization and evaluation of antioxidant activity of propolis collected in the atlántic department, Colombia." Revista U.D.C.A Actualidad \& Divulgación Científica, 15(2), 303-311.

Rosero-Delgado, E. A., and Dustet-Mendoza, J. C. (2017). "Cinética de la fermentación en estado sólido de cascarilla de arroz y bagazo de caña con Auricularia auricula," ICIDCA Instituto Cubano de Investigaciones de los Derivados de la Caña de Azúcar. Sobre los Derivados de la Caña de Azúcar, vol. 51, núm. 1, pp. 28-38, https://www.redalyc.org/articulo.oa?id=223153894005

Rue, E. A., Rush, M. D., and van Breemen, R. B. (2017). "Procyanidins: a comprehensive review encompassing structure elucidation via mass spectrometry." Phytochemistry Reviews, 17(1), 1-16. DOI: 10.1007/s11101-017-9507-3

Shabani, Z., and Sayadi, A. (2014). "The antimicrobial in vitro effects of different concentrations of some plant extracts including tamarisk, march, acetone and mango kernel." Journal of Applied Pharmaceutical Science, 4(5), 75-79. DOI: 10.7324/JAPS.2014.40514

Sogi, D. S., Siddiq, M., Greiby, I., and Dolan, K. D. (2013). "Total phenolics, antioxidant activity, and functional properties of 'Tommy Atkins' mango peel and kernel as affected by drying methods." Food Chemistry, 141(3), 2649-2655. DOI: 10.1016/j.foodchem.2013.05.053

Subbiya, A., Mahalakshmi, K., Pushpangadan, S., Padmavathy, K., Vivekanandan, P., and Sukumaran, V. (2013). "Antibacterial efficacy of Mangifera indica L. kernel and Ocimum sanctum L. leaves against Enterococcus faecalis dentinal biofilm." Journal of Conservative Dentistry, 16(5), 454-457. DOI: 10.4103/09720707.117507.

Torres-León, C., Rojas, R., Contreras-Esquivel, J. C., Serna-Cock, L., Belmares-Cerda, R. E., and Aguilar, C. N. (2016). "Mango seed: Functional and nutritional properties." Trends in Food Science and Technology, 55, 109-117. DOI: 10.1016/j.tifs.2016.06.009

Vaghasiya, Y., Dave, R., and Chanda, S. (2011). "Phytochemical Analysis of Some Medical Plants from Western Region of India." Research Journal of Medicinal Plant, 1-10. DOI: 10.3923/rjmp.2011

Vargas-León, E. A., Díaz-Batalla, L., González-Cruz, L., Bernardino-Nicanor, A., Castro-Rosas, J., Reynoso-Camacho, R., \& Gómez-Aldapa, C. A. (2018). "Effects of acid hydrolysis on the free radical scavenging capacity and inhibitory activity of the angiotensin converting enzyme of phenolic compounds of two varieties of jamaica (Hibiscus sabdariffa)". Industrial Crops and Products, 116, 201-208. DOI: 10.1016/j.indcrop.2018.02.044

Xing, J., Li, R., Li, N., Zhang, J., Li, Y., Gong, P., Gao, D., Liu, H., and Zhang, Y. 
(2015). “Anti-inflammatory effect of procyanidin B1 on LPS-treated THP1 cells via interaction with the TLR4-MD-2 heterodimer and p38 MAPK and NF- $\kappa \mathrm{B}$ signaling." Molecular and Cellular Biochemistry, 407(1-2), 89-95. DOI: 10.1007/s11010-015-2457-4

Article submitted: February 2, 2020; Peer review completed: March 28, 2020; Revised version received and accepted: May 7, 2020; Published: May 19, 2020.

DOI: 10.15376/biores. 15.3.5264-5280 


\section{SUPPLEMENTARY INFORMATION}

Table S1. Percentage Inhibition of Ethanol Extracts in Bacteria and Mushrooms

\begin{tabular}{|c|c|c|c|c|c|}
\hline $\begin{array}{l}\text { Mango } \\
\text { variety }\end{array}$ & $\begin{array}{c}\text { Concentration } \\
(\mu \mathrm{L} / \mathrm{mL})\end{array}$ & \% INH E. coli & \% INH S. aureus & $\begin{array}{c}\% \text { INH } \\
\text { Fusarium sp }\end{array}$ & $\begin{array}{c}\text { \% INH } \\
\text { Rhizopus sp }\end{array}$ \\
\hline \multirow{7}{*}{ Yulima } & 2000 & - & - & - & - \\
\hline & 1000 & $55.92 \pm 3.12$ & $62.70 \pm 5.80$ & $40.92 \pm 6.27$ & $89.29 \pm 0.63$ \\
\hline & 500 & $55.50 \pm 0.70$ & $92.42 \pm 1.16$ & $23.20 \pm 3.57$ & $76.58 \pm 16.16$ \\
\hline & 250 & $57.60 \pm 1.19$ & $98.23 \pm 1.23$ & $15.65 \pm 8.36$ & $33.91 \pm 2.31$ \\
\hline & 125 & - & $94.58 \pm 2.14$ & $15.86 \pm 5.97$ & $25.53 \pm 3.95$ \\
\hline & 62.5 & - & $82.50 \pm 4.74$ & $18.41 \pm 7.67$ & $2.68 \pm 4.13$ \\
\hline & 32 & $40.85 \pm 4.6$ & $62.18 \pm 11.56$ & $16.46 \pm 6.99$ & $20.94 \pm 7.60$ \\
\hline \multirow{7}{*}{ Manzano } & 2000 & - & - & - & - \\
\hline & 1000 & $58.74 \pm 4.4$ & - & $45.77 \pm 7.94$ & $89.60 \pm 2.11$ \\
\hline & 500 & $54.63 \pm 1.25$ & $86.25 \pm 3.52$ & $17.95 \pm 7.0$ & $87.56 \pm 17.24$ \\
\hline & 250 & $52.84 \pm 2.80$ & $97.67 \pm 0.71$ & $18.12 \pm 3.65$ & $70.55 \pm 16.52$ \\
\hline & 125 & - & $87.56 \pm 4.37$ & $17.84 \pm 2.15$ & $39.06 \pm 5.3$ \\
\hline & 62.5 & - & $78.29 \pm 8.05$ & $10.72 \pm 3.26$ & $37.31 \pm 4.75$ \\
\hline & 32 & $38.46 \pm 5.75$ & - & $22.32 \pm 3.29$ & $21.72 \pm 5.53$ \\
\hline \multirow{7}{*}{ Mariquiteño } & 2000 & - & - & - & - \\
\hline & 1000 & $35.47 \pm 3.67$ & $71.73 \pm 9.31$ & $37.65 \pm 5.63$ & $87.84 \pm 6.30$ \\
\hline & 500 & $54.63 \pm 2.49$ & $86.17 \pm 3.01$ & $18.25 \pm 3.21$ & $59.63 \pm 10.11$ \\
\hline & 250 & $34.18 \pm 4.16$ & $97.84 \pm 1.19$ & $19.67 \pm 3.72$ & $27.45 \pm 8.22$ \\
\hline & 125 & - & $95.69 \pm 3.17$ & $17.19 \pm 4.83$ & $22.04 \pm 1.68$ \\
\hline & 62.5 & - & $83.62 \pm 6.88$ & $18.72 \pm 4.67$ & $19.03 \pm 7.08$ \\
\hline & 32 & $17.00 \pm 12.41$ & - & $18.32 \pm 3.5$ & $26.68 \pm 8.58$ \\
\hline \multirow{7}{*}{ Común } & 2000 & - & - & - & - \\
\hline & 1000 & $33.30 \pm 2.15$ & - & $41.31 \pm 3.58$ & $87.08 \pm 1.30$ \\
\hline & 500 & $41.19 \pm 6.92$ & $75.56 \pm 4.86$ & $28.73 \pm 1.35$ & $78.73 \pm 19.59$ \\
\hline & 250 & $40.02 \pm 1.56$ & $93.78 \pm 1.71$ & $23.13 \pm 4.48$ & $41.02 \pm 8.04$ \\
\hline & 125 & - & $97.26 \pm 1.03$ & $16.62 \pm 10.62$ & $25.93 \pm 15.44$ \\
\hline & 62.5 & - & $91.71 \pm 4.21$ & $20.13 \pm 4.10$ & $30.82 \pm 7.20$ \\
\hline & 32 & $16.70 \pm 7.18$ & $55.53 \pm 7.21$ & 19. $16 \pm 6.48$ & $27.25 \pm 11.21$ \\
\hline
\end{tabular}

